\title{
SYMPOSIUM ON THE ROME STATUTE AT TWENTY
}

\section{THE IMMUNITY OF HEADS OF STATES OF NONPARTIES IN THE EARLY YEARS OF THE ICC}

\author{
Dapo Akande*
}

More than any other international criminal tribunal, the International Criminal Court (ICC) has, in its early years, pursued cases against heads of state. The Court issued arrest warrants for President Omar al Bashir of Sudan and for Muammar Gaddafi while he was Libya's head of state, and it charged Uhuru Kenyatta shortly before he became head of state of Kenya. These attempts to prosecute heads of states have not only led to tensions between the Court and the African Union, ${ }^{1}$ but also pit the desire to hold senior leaders accountable for grave international crimes against the customary international law principle that certain senior state officials-especially heads of state- have immunity from foreign criminal jurisdiction by virtue of their status, including immunity from arrest and their inviolability when abroad. ${ }^{2}$

The institution of proceedings against Bashir and Gaddafi, as heads of states not party to the ICC Statute, has raised questions as to how the nature of the ICC as a treaty-based institution, whose Statute only binds parties to that treaty, should be reconciled with the Court's exercise of jurisdiction in circumstances where the interests and/or legal rights of those nonparty states are implicated. ${ }^{3}$

The way in which the Court, states, and the Security Council have dealt with head-of-state immunity over the last decade has damaged the Court's authority. Not only has the Court's request for the arrest and surrender of Bashir not been respected by states, but the Court's own actions on the issue have also been unsatisfactory. Although pre-trial chambers (PTCs) have consistently concluded that the position of the accused as a head of state does not exempt the accused from proceedings before the Court or from arrest by states parties, they have offered different and inconsistent reasons. ${ }^{4}$ For

* Professor of Public International Law, University of Oxford \& Fellow, Exeter College, Oxford.

${ }^{1}$ See Gino Naldi \& Konstantinos Magliveras, The International Criminal Court and the African Union: A Problematic Relationship, in THE International Criminal Court and Africa (Charles Chernor Jalloh \& Ilias Bantekas eds., 2017).

2 See Arrest Warrant of 11 April 2000 (Dem. Rep. Congo v. Belg.), 2002 ICJ Rer. 3, paras. 54-55 (Feb. 14) [hereinafter Arrest Warrant Case]; Draft Articles 3 and 4 of the Draft Articles on Immunity of State Officials from Foreign Criminal Jurisdiction, Int'l Law Comm'n, Report on Its Sixty-Ninth Session, UN Doc. A/72/10, at 175 (2017). See generally Dapo Akande \& Sangeeta Shah, Immunities, International Crimes and Foreign Domestic Courts, 21 Eur. J. InT'L L. 815 (2010).

${ }^{3}$ See Dapo Akande, The Jurisdiction of the International Criminal Court Over Nationals of Non-Parties: Legal Basis and Limits, 1 J. INT'L CRIM. JusT. 618 (2003).

${ }^{4}$ See Decision on the Prosecution's Application for a Warrant of Arrest Against Omar Hassan Ahmad Al Bashir, ICC-02/05-01/09-3 (Mar. 4, 2009) [hereinafter Bashir Arrest Warrant Decision]; Decision Pursuant to Article 87(7) of the Rome Statute on the Refusal of the Republic of Chad to Comply with the Cooperation Requests Issued by the Court with Respect to the Arrest and Surrender of Omar Hassan Ahmad Al Bashir, ICC-02/05-01/09-140 (Dec. 13, 2011) [hereinafter Bashir Malawi/Chad Decision]; Decision on the Cooperation of the

\footnotetext{
The American Society of International Law and Dapo Akande (C) 2018. This is an Open Access article, distributed under the terms of the Creative Commons Attribution licence (http://creativecommons.org/licenses/by/4.0/), which permits unrestricted re-use, distribution, and reproduction in any medium, provided the original work is properly cited.
} 
the first time, the matter is before the Appeals Chamber, ${ }^{5}$ which has an opportunity to bring much needed clarity to the legal issues.

\section{Two Levels of Immunity}

The question of head-of-state immunity in relation to ICC proceedings arises at two different levels. First, there is the question of whether a serving head of state is immune from proceedings before the Court itself. Second, there is the question of whether a head of state is immune from arrest by another state which is acting to execute an arrest warrant issued by the Court. The first question relates to the "vertical" legal relationship between the Court and the state of the accused. The second relates to the "horizontal" relationship between states and to whether the Court should require ICC parties to risk violating obligations they would ordinarily owe to the state of the accused.

Articles 27 and 98 of the Statute address immunity of state officials, with Article 27 primarily removing immunity of officials at the vertical level before the Court, ${ }^{6}$ and Article 98 addressing the horizontal level by requiring the Court not to request arrest and surrender where the requested state would have to violate its obligations with respect to the immunity of third states.

Unfortunately, the Court has not always appreciated the distinction between the "vertical" and "horizontal" levels of immunity. In its first decision issuing an arrest warrant for Bashir, the PTC stated that "the current position of Omar Al Bashir as Head of a state which is not a party to the Statute, has no effect on the Court's jurisdiction over the present case." 7 However, the PTC failed to consider whether Bashir's immunity must be respected at the national level. This was an amazing oversight, since Article 98(1) of the ICC Statute addresses this very question. Regrettably, the PTC ignored Article 98(1) in its analysis and proceeded to request arrest and surrender in circumstances where immunities were clearly in issue. Also remarkable is that the PTC analyzed the question of head-of-state immunity of a nonparty solely from the perspective of the Statute. While "the jurisdiction and functioning of the Court [are] ... governed by the Statute," should be interpreted in the light of other applicable rules of international law. ${ }^{9}$

The African Union, relying on Article 98, consistently objected to the PTC's issuance of an arrest warrant for Bashir and called for its member states not to cooperate with the Court in arresting Bashir given his head-of-state immunity. ${ }^{10}$ However, the Court did not make an explicit decision on immunity for nearly three years after the Bashir Arrest Warrant Decision, despite having several opportunities to do so.

Democratic Republic of the Congo Regarding Omar Al Bashir's Arrest and Surrender to the Court, ICC-02/05-01/09-195 (Apr. 9, 2014); Decision Under Article 87(7) of the Rome Statute on the Non-Compliance by South Africa with the Request by the Court for the Arrest and Surrender of Omar Al-Bashir, ICC-02/05-01/09-302 July 6, 2017) [hereinafter Bashir South African Decision]; Decision Under Article 87 (7) of the Rome Statute on the Non-Compliance by Jordan with the Request by the Court for the Arrest and Surrender of Omar Al-Bashir, ICC-02/05-01/09-309 (Dec. 11, 2017).

5 See The Hashemite Kingdom of Jordan's Appeal Against the "Decision under Article 87(7) of the Rome Statute on the Non-Compliance by Jordan with the Request by the Court for the Arrest and Surrender [of] Omar Al-Bashir", ICC-02/05-01/09-326 (Mar. 12, 2018).

${ }^{6}$ See also Dapo Akande, International Law Immunities and the International Criminal Court, 98 AJIL 407, 423-26 (2004) (arguing that Article 27 also addresses the horizontal level by removing immunity of officials of states parties in the territory of other states parties); Bashir Malawi/ Chad Decision, supra note 4, at para. 18 (adopting this view); Bashir South African Decision, supra note 4, at paras. 71-81 (same).

${ }^{7}$ Bashir Arrest Warrant Decision, supra note 4, para. 41.

${ }^{8}$ Rome Statute of the International Criminal Court art. 1, July 17, 1998, 2187 UNTS 3 [hereinafter Rome Statute].

${ }^{9}$ Vienna Convention on the Law of Treaties art. 31(3)(c), May 23, 1969, 1155 UNTS 331.

10 See, e.g., Assembly of the African Union, Decision on the Meeting of African States Parties to the Rome Statute of the International Criminal Court (ICC), Assembly/AU/Dec.245 (XIII), paras. 9,10 (July 3, 2009); Assembly of the African Union, Decision on the Progress 
Another PTC finally addressed the immunity question in concluding that Malawi and Chad had breached their obligations by failing to arrest Bashir when he visited those countries in late $2011 .{ }^{11}$ In these decisions, the PTC moved from relying solely on the Statute to considering the effect of customary international law with regard to immunity at both the vertical and horizontal levels. Regarding the vertical level, the PTC held that customary international law creates a general exception to head-of-state immunity in prosecutions before international courts. On the horizontal level, the PTC held that there is no conflict between states parties' obligations towards the Court and their obligations under customary international law, and therefore Article 98(1) of the Statute does not apply.

\section{Customary International Law, Immunity, and International Tribunals}

In reaching its decision, the PTC in the Bashir Malawi/Chad Decision relied on the statutes of previous international criminal tribunals, which provided that official position does not relieve the accused from criminal responsibility. This was supposed to be impressive evidence for a rule of customary international law that the heads of states are not immune from the jurisdiction of international tribunals. But these precedents do not establish that the head of a state not bound by the instruments establishing an international tribunal will nonetheless lack immunity from the jurisdiction of that tribunal.

First, these provisions address whether the state official bears criminal responsibility, which is not the same as regulating immunity from the tribunal's jurisdiction. Second, and more importantly, to the extent that these other tribunals' statutes can be construed as removing immunity, they were binding on the relevant states (i.e., those of the accused). ${ }^{12}$ Likewise, the ICJ's decision in the Arrest Warrant Case ${ }^{13}$ only states that foreign ministers may be subject to criminal proceedings in "certain international criminal courts, where they have jurisdiction." 14 The only judicial precedent that might support the PTC's conclusion is that of the Special Court for Sierra Leone in the Charles Taylor Case. ${ }^{15}$ But the logic of that decision is just as flawed as the PTC's. Meanwhile, the ICTY Appeals Chamber in Prosecutor v. Blaskkic ${ }^{16}$ recognized that immunities do not disappear simply because the tribunal is international, as did Judge Shahabuddeen in his dissenting opinion in Prosecutor v. Krstic. ${ }^{17}$

Towards the end of its decision, the PTC states that

it is the view of the Chamber that when cooperating with this Court and therefore acting on its behalf, states Parties are instruments for the enforcement of the jus puniendi of the international community whose exercise has been entrusted to this Court when states have failed to prosecute those responsible for the crimes within its jurisdiction. ${ }^{18}$

Report of the Commission on the Implementation of Decision Assembly/AU/Dec.270(XIV) on the Second Ministerial Meeting on the Rome Statute of the International Criminal Court (ICC), Assembly/AU/Dec. 296 (XV), paras. 4-5 (July 27, 2010); Assembly of the African Union, Decision on the Progress Report of the Commission on the Implementation of the Assembly Decisions on the International Criminal Court (ICC), Assembly/AU/Dec.397(XVIII), at 1-2 (Jan. 29-30, 2012).

${ }^{11}$ Bashir Malawi/Chad Decision, supra note 4.

12 See Akande, supra note 3, at 628-31.

13 Arrest Warrant Case, supra note 2.

${ }^{14}$ Id. at para. 61 (emphasis added).

15 Prosecutor v. Charles Taylor, Case No. SCSL-03-01-I, Decision on Immunity from Jurisdiction (May 31, 2004).

16 Prosecutor v. Blaškić, Case No. IT-95-14-AR108, Decision on the Objection to the Issue of Subpoena duces Tecume (Int'l Crim. Trib. for the Former Yugoslavia, July 18, 1997).

${ }^{17}$ Prosecutor v. Krstic, Case No. IT-98-33-A, Decision on Application for Subpoenas, paras. 11-12, Dissenting Opinion (Int'l Crim. Trib. for the Former Yugoslavia, July 1, 2003).

18 Bashir Malawi/Chad Decision, supra note 4, at para. 46 
The underlying argument, it seems, is that while the international law immunity of foreign heads of state is necessary to prevent national interference in the ability of a foreign state to engage in international action, this danger does not arise with international courts since these are independent of states and act impartially. ${ }^{19}$ However, this distinction does not withstand scrutiny as international courts are often created by states, as was the ICC; what a state cannot do individually, it also cannot do by agreement with others.

Further, the PTC fails to define when an international court qualifies as a tribunal that the international community has entrusted with its jus puniendi. Is the ICC to be regarded as such a tribunal now because of the number of its states parties (which is still less than two-thirds of the states of the world)? What about when the Statute first came into force with only sixty parties? Under this reasoning, the Malabo Protocol on the African Court of Human and People's Rights, which expands the jurisdiction of that court to deal with international crimes, could have provided for prosecution of any sitting head of state, of any state worldwide, even with respect to crimes committed outside Africa. And what of crimes that are within the Court's jurisdiction due to an amendment to the Statute, which only requires one state's ratification to come into force ${ }^{20}$ Indeed, it is possible that some of the amended crimes are not even crimes under customary international law. ${ }^{21}$ Such reasoning would seem to allow international tribunals that can exercise jurisdiction over noninternational crimes (e.g., the Special Court for Sierra Leone, the proposed criminal chamber of the African Court, the Special Tribunal for Lebanon) to prosecute sitting heads of state even of states not bound by the instrument establishing the tribunal.

Even if the PTC were right that there is no immunity from prosecution before international courts (the vertical level), it failed to explain how customary international law allows national authorities to arrest foreign heads of state in support of a request from an international court (the horizontal level). ${ }^{22}$ There is certainly no practice to suggest such a rule. Indeed, many states that have national legislation implementing the ICC Statute draw a distinction between the immunity of states parties to the Statute and the immunities of those states not party. ${ }^{23}$

Finally, the PTC's statement that "the unavailability of immunities with respect to prosecutions by international courts applies to any act of cooperation by states which forms an integral part of those prosecutions" 24 would, in violation of principles of treaty interpretation, seem to render Article 98 redundant. On this view, national authorities may never raise the immunity of a state as an obstacle to cooperation with the ICC.

\section{Security Council Referrals and Immunity}

In later decisions, ICC PTCs have charted a different course, rejecting Bashir's immunity, even before national authorities, on the basis that the UN Security Council's referral of the Sudan (Darfur) situation to the ICC waived or removed that immunity. Although this is a much better route for concluding that ICC states parties are required to arrest Bashir, the Court's change of course has not been entirely unproblematic.

First, the Bashir DRC Decision did not acknowledge the change in reasoning and made no reference to the different reasoning of the Bashir Malawi/Chad Decision. Second, the reasoning of the Bashir DRC Decision was

\footnotetext{
19 See Paola Gaeta \& Patryk Labuda, Trying Sitting Heads of State: The African Union Versus the ICC in the Al Bashir and Kenyatta Cases, in THE International Criminal Court and Africa, supra note 1, at 138, 146-47.

20 See Rome Statute, supra note 8, art. 121(5).

${ }^{21}$ See Dapo Akande, Customary International Law and the Addition of New War Crimes to the Statute of the ICC, EJIL:TALk! (Jan. 2, 2018).

22 See Gaeta \& Labuda, supra note 19, at 147-48.

${ }^{23}$ See the relevant legislation of the United Kingdom, Malta, Ireland, and Samoa.

${ }^{24}$ Bashir Malawi/Chad Decision, supra note 4, at para. 44.
} 
not entirely convincing. ${ }^{25}$ The PTC justified the lack of immunity on the basis that the Security Council had "waived" the immunity when it imposed an obligation on Sudan to cooperate with the Court. But the failure of Sudan to cooperate simply means that Sudan is in breach of its Charter obligation; it does not affect the position of Sudan vis-à-vis the Court or vis-à-vis other states.

However, the PTC in the Bashir South Africa Decision adopted a different (and in this author's view, more convincing) variant of this argument. In this 2017 decision, the PTC reasoned that the Security Council's referral places Sudan in a similar position to that of ICC states parties, such that Sudan is bound by Article 27(2) of the Statute. This provision then removes the immunity of the Sudanese head of state not only before the Court, but also in relation to ICC states parties. In short, Sudan was no longer, as a result of the referral, entitled to rely on Article 98(1) of the Statute. In addition, the minority held that since Bashir was charged with genocide and Sudan is party to the Genocide Convention, that Convention removes head-of-state immunity with regard to the ICC (and states cooperating with it). ${ }^{26}$ Thus, although the Statute does not bind the non-party (Sudan), its UN Charter obligation to accept decisions of the UN Security Council means that it is bound to accept the ICC's jurisdiction-and provisions for making that jurisdiction effective (such as Article 27).

Once Article 27 is deemed binding on a nonparty (through the Security Council resolution), that nonparty's position under Article 98 changes: it is now in the same position as a state party. As the nonparty no longer has the benefit of international law immunities, a state party would not violate its international law obligations by arresting and surrendering that nonparty's head of state to the Court.

Still, it needs to be established which nonparty is thus bound by the Security Council referral. It is certainly not the case that the Security Council's referral imposes obligations on all nonparties. Indeed, Paragraph 2 of the Resolution explicitly recognizes that nonparties other than Sudan are not bound by the obligation to cooperate with the Court. Therefore, it was not entirely wrong for the PTC in the Bashir DRC Decision to focus on the Security Council obligation on Sudan to cooperate. What was wrong was to hold that this provision amounted to a waiver of Sudan's immunity. Rather, the provision identified that Sudan was bound by the obligations under the Statute relating to cooperation and to the Court's jurisdiction. Those obligations include an obligation to accept that immunity was removed (at both the vertical and horizontal levels) in relation to proceedings before the Court.

\section{Lessons Learned?}

The way in which the ICC has handled the question of immunity has strained the relations between the Court, African states, and the African Union. It was most unfortunate that the ICC judges avoided dealing with the immunity issue for so long, since the African Union raised a reasonable argument regarding nonparty head-of-state immunity. The resulting tension with African states was somewhat damaging to the Court. Even when the Court began to address the issue, it failed to articulate a consistent line of reasoning. However, it has in the Bashir South Africa Decision finally adopted a more persuasive reason for the lack of immunity. How the Appeals Chamber handles this question is important because, quite apart from head-of-state immunity, other immunity issues will arise, including questions about diplomatic immunity, the immunity of special missions, and who exactly is entitled to immunity ratione personae. When these questions arise, one hopes that the Court will have learned lessons from the first twenty years of the Rome Statute.

\footnotetext{
25 See Andre de Hoogh \& Abel Knottnerus, ICC Issues New Decision on Al-Bashir's Immunities - But Gets the Law Wrong ... Again, EJIL:TALk! (Apr. 18, 2014); Paola Gaeta, The ICC Changes Its Mind on the Immunity from Arrest of President Al Bashir, But It Is Wrong Again, OpINIO Juris (Apr. 23, 2014).

${ }^{26}$ See Dapo Akande, The Legal Nature of Security Council Referrals to the ICC and Its Impact on Al Bashir's Immunities, 7 J. INT'L CRIM. Just. 333 (2009); Dapo Akande, The Impact of the Genocide Convention on the Obligation to Implement ICC Arrest Warrants, in CONTEMPORARY Issues FACING the International Criminal Court 77 (Richard H. Steinberg ed., 2016).
} 